\title{
PENGARUH INOKULASI FUNGI MIKORIZA ARBUSKULAR DAN PENAMBAHAN BAHAN ORGANIK PADA TANAH PASCA PENAMBANGAN GALIAN C TERHADAP PERTUMBUHAN DAN SERAPAN HARA P TANAMAN JAGUNG (Zea mays L.)
}

\author{
Ina Febria Ginting, Sri Yusnaini, Dermiyati \& Maria Viva Rini \\ Jurusan Agroteknologi, Fakultas Pertanian, Universitas Lampung \\ Jl. Prof. Soemantri Brojonegoro, No. 1 Bandar Lampung 35145 \\ Email:inaf42@yahoo.com
}

\begin{abstract}
ABSTRAK
Tanah pasca galian $\mathrm{C}$ merupakan tanah yang bermasalah karena rendahnya unsur hara dan C-organik. Penelitian ini bertujuan untuk mengetahui pengaruh inokulasi FMA dan penambahan bahan organik dalam meningkatkan pertumbuhan dan serapan hara P tanaman jagung pada tanah pasca penambangan galian C. Perlakuan disusun secara faktorial $3 \times 4$ dalam Rancangan Acak Kelompok (RAK) dengan 3 kelompok. Faktor pertama, inokulasi FMA dengan 3 taraf, yaitu: tanpa FMA (0 spora), 250 spora, dan 500 spora. Faktor kedua, penambahan bahan organik dengan 4 taraf, yaitu: tanpa bahan organik $(0 \%), 20 \%, 40 \%$, dan $60 \%$ dari volume tanah. Data diuji dengan analisis ragam kemudian dilanjutkan dengan uji nilai tengah menggunakan BNT pada á $=5 \%$. Hasil penelitian menunjukkan bahwa inokulasi FMA meningkatkan infeksi akar dan pertumbuhan tanaman jagung melalui volume akar. Hasil infeksi akar meningkat setelah diberikan FMA(250 spora dan 500 spora), sedangkan volume akar tertinggi adalah pada inokulasi dosis 250 spora. Penambahan bahan organik meningkatkan infeksi akar dan serapan hara $\mathrm{P}$ tanaman jagung. Hasil infeksi akar tertinggi pada perlakuan tanpa bahan organik $(0 \%)$ dan dosis $60 \%$ bahan organik. Sedangkan hasil serapan hara P tertinggi ditunjukkan pada dosis $40 \%$ bahan organik. Interaksi FMA dan bahan organik terjadi pada tinggi tanaman 2 MST. Hasil tinggi tanaman terbaik ditunjukkan pada kombinasi FMA 250 spora dengan tanpa bahan organik yaitu $59,97 \mathrm{~cm}$.
\end{abstract}

Kata Kunci: Bahan organik, FMA, tanah pasca galian C.

\section{PENDAHULUAN}

Tambang galian golongan $\mathrm{C}$ merupakan penambangan yang mengambil hasil bumi berupa pasir, kerikil, batu, tanah liat, dan tanah urugan. Tanah pasca galian $\mathrm{C}$ memiliki sifat daya serap air yang rendah, tidak dapat menahan air dalam waktu yang lama, miskin unsur hara, dan mudah mengalami erosi, sehingga memiliki kendala apabila dijadikan lahan pertanian. Oleh sebab itu, diperlukan alternatif penambahan inokulum Fungi Mikoriza Arbuskular (FMA) dan bahan organik yang bertujuan untuk membantu meningkatkan kualitas tanah, terutama ketersediaan air dan unsur hara bagi pertumbuhan tanaman.

Fungi Mikoriza Arbuskular merupakan fungi yang bersimbiosis dengan akar tanaman dan bersifat obligat simbion, sehingga memerlukan tanaman inang untuk tumbuh dan berkembang. Musfal (2010) menyatakan bahwa FMA dapat bersimbiosis dengan 97\% famili tanaman tingkat tinggi, dan tanaman jagung merupakan salah satu jenis tanaman yang berpotensi sebagai tanaman inang bagi kehidupan FMA (Hasibuan et al.,
2014). Selain tanaman inang, efektifitas FMA dipengaruhi oleh dosis spora dan bahan organik (Widiastuti et al., 2003).

Selain inokulasi FMA, penambahan bahan organik juga dapat dijadikan alternatif untuk mengatasi ketidaksuburan pada tanah pasca galian C (Syekhfani, 1993). Bahan organik merupakan bagian dari tanah yang bersumber dari jaringan-jaringan tanaman maupun hewan yang telah mengalami perubahan bentuk akibat proses dekomposisi yang terjadi di dalam tanah. Bahan organik mampu meningkatkan ketersediaan unsur hara bagi tanaman melalui proses dekomposisi, selain itu juga dapat meningkatkan aktivitas mikroba di dalam tanah.

Perbaikan tanah pasca galian $\mathrm{C}$ menggunakan inokulasi FMA dan bahan organik diharapkan dapat meningkatkan kesuburan tanah sehingga unsur hara bagi tanaman dapat terpenuhi. Menurut Badan Penelitian dan Pengembangan Pertanian (2008) untuk membudidaya kan tanaman jagung perlu diperhatikan kadar air, media tanam yang subur untuk memenuhi kebutuhan hara sehingga dapat bereproduksi dengan baik. Jagung membutuhkan unsur hara nitrogen, fosfor, dan kalium. 
Penelitian ini bertujuan untuk mengetahui pengaruh inokulasi FMA dan penambahan bahan organik dalam meningkatkan pertumbuhan dan serapan hara $\mathrm{P}$ tanaman jagung pada tanah pasca penambangan galian $\mathrm{C}$.

\section{BAHAN DAN METODE}

Penelitian ini dilaksanakan di Fakultas Pertanian Universitas Lampung pada bulan Juli 2016 hingga Desember 2016. Perlakuan disusun dalam rancangan acak kelompok yang disusun secara faktorial $3 \times 4$ dengan 3 kelompok, sehingga terdapat 36 satuan percobaan. Faktor pertama adalah inokulasi FMA dengan 3 taraf yaitu $M_{0}=$ tanpa spora, $M_{1}=250$ spora dan $M_{2}=500$ spora. Faktor kedua adalah penambahan bahan organik dengan 4 taraf, yaitu $\mathrm{B}_{0}=$ tanpa bahan organk, $\mathrm{B}_{1}=20 \%$, $\mathrm{B}_{2}=40 \%$, dan $\mathrm{B}_{3}=60 \%$. Pengelompokan berdasarkan intensitas cahaya.

Persiapan Media Tanam dan Penambahan Bahan Organik. Media tanam untuk penelitian ini adalah tanah pasca pertambangan galian $\mathrm{C}$. Tanah diambil dari pertambangan batu dan kerikil di Jalan Soekarno Hatta, Panjang, Bandar Lampung. Tanah dibawa ke rumah kaca Fakultas Pertanian Universitas Lampung. Sebelum digunakan, tanah pasca galian $\mathrm{C}$ yang masih berupa bongkahan dihaluskan kemudian diayak menggunakan ayakan berukuran $0,5 \mathrm{~cm}$ dan ditambahkan bahan organik untuk meningkatkan bahan

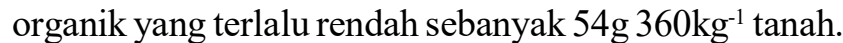
Media tanam disiapkan, tanah yang telah dicampur bahan organik dicampurkan dengan perlakuan bahan organik kotoran sapi, masing-masing dosis perlakuan, yaitu $0 \%$ (tanpa bahan organik), 20\%, 40\% dan 60\%.

Penanaman Benih Jagung dan Inokulasi Fungi Mikoriza Arbuskula (FMA). Inokulasi FMA menggunakan 3 taraf dosis, yaitu: 0 spora (tanpa spora), 250 spora dan 500 spora. Benih jagung dimasukkan ke dalam polybag masing-masing diisi 2 benih jagung bersamaan dengan inokulasi FMA. Lubang tanam dibuat sedalam $\pm 7 \mathrm{~cm}$, kemudian inokulum campuran FMA (Glomus sp., Gigaspora sp., Enthropospora sp. dan Acaulospora sp.) sebanyak $\pm 1 / 3$ inokulum dari dosis perlakuan, dimasukkan ke dalam lubang tanam, kemudian ditutup dengan tanah, lalu benih jagung dan \pm $2 / 3$ inokulum dari dosis perlakuan dimasukkan menutupi benih jagung, kemudian ditutup dengan tanah. Hal yang sama dilakukan untuk setiap perlakuan. Pengamatan meliputi analsis tanah awal, tinggi tanaman $(\mathrm{cm})$ diukur setiap minggu hingga $8 \mathrm{MST}$, volume akar (ml), bobot berangkasan kering (g), infeksi akar (\%), serapan hara $\mathrm{P}\left(\mathrm{g} \operatorname{tanaman}^{-1}\right)$, dan analisis tanah akhir dilakukan setelah panen (8 MST).

\section{HASIL DAN PEMBAHASAN}

Hasil analisis tanah awal (Tabel 1) menunjukkan tanah pasca galian $\mathrm{C}$ memiliki tingkat kesuburan yang rendah. Diketahui dari sifat kimianya yang memiliki tingkat kemasaman tinggi $(5,44)$, kandungan C-organik yang rendah $(0,32 \%)$, kandungan NPK rendah, masingmasing $0,05 \% ; 0,21 \mathrm{ppm} ; 0,21 \mathrm{me}^{100 \mathrm{~g}^{-1}}$. Rendahnya tingkat kesuburan tanah pasca galian $\mathrm{C}$ disebabkan tanah telah kehilangan tanah bagian atas (topsoil). Analisis terhadap pupuk kandang kotoran sapi yang digunakan menunjukkan hasil kandungan hara yang tinggi dan memiliki $\mathrm{C} / \mathrm{N}$ ratio 19,60 (Tabel 1) yang menunjukkan bahwa bahan organik berupa pupuk kandang kotoran sapi sudah matang dan dapat langsung diaplikasikan.

Hasil analisis tanah akhir (Tabel 2), menunjukkan bahwa inokulasi FMA dan penambahan bahan organik dengan berbagai jenis dosis mampu memperbaiki sifat kimia tanah pasca galian CPerbaikan dilihat dari perubahan $\mathrm{pH}$ tanah dan kandungan $\mathrm{C}$-organik tanah yang semakin meningkat. Tanah pasca galian $\mathrm{C}$ yang semula bersifat masam $(5,44)$ setelah diberi perlakuan inokulum FMA dan bahan organik mengalami kenaikan $\mathrm{pH}$, yaitu berkisar 6,2-7,3. Begitu pula kandungan Corganik yang semula hanya $0,32 \%$, setelah diberi inokulan FMA dan bahan organik mengalami peningkatan $(1,0 " 3,7)$ seiring dengan meningkatnya dosis bahan organik yang diberikan.

Akibat aktivitas penambangan batu yang dilakukan secara terus menerus mengakibatkan terkikisnya lapisan topsoil pada tanah sehingga unsur hara yang tersedia dan kesuburan tanah berkurang. Hasil analisis tanah awal (Tabel 1) menunjukkan kesuburan tanah rendah yang dicirikan dengan keadaan tanah yang masam $(5,44)$, kadar C-organik yang rendah sebesar $0,32 \%$, NPK yang rendah masing-masing adalah $0,05 \% ; 9,97 \mathrm{ppm} ; 0,21$ me $100 \mathrm{~g}^{-1}$, serta kadar air di dalam tanah juga rendah $5,11 \%$. Inokulasi FMA dan penambahan bahan organik mampu memperbaiki sifat kimia tanah pasca galian $\mathrm{C}$ (Tabel 2). Kenaikan $\mathrm{pH}$ tanah ini disebabkan oleh adanya aktivitas dari FMA berupa proses metabolisme serta pelepasan senyawa organik berupa asam amino yang mampu mengikat kation $\mathrm{Al}$ sehingga $\mathrm{pH}$ tanah meningkat (Cumming and Ning, 2003).

Pada Tabel 2 menujukkan bahwa bahan organik mempengaruhi $\mathrm{pH}$ tanah, hal ini diduga akibat hasil dekomposisi bahan organik sehingga kation-kation basa sebagai penyumbang ion $\mathrm{OH}^{-}$terlepas ke dalam tanah. Pada pemberian dosis bahan organik sebanyak $20 \%$ $40 \%$, pH meningkat menjadi 7,0-7,1, sedangkan dosis $60 \%$ meningkatkan $\mathrm{pH}$ tanah menjadi 7,3. Perubahan C-organik tanah disebabkan oleh adanya aktivitas FMA 
Tabel 1. Hasil analisis tanah awal pasca galian $\mathrm{C}$ dan pupuk kandang sapi yang digunakan pada penelitian.

\begin{tabular}{llcl}
\hline Sifat Kimia & Metode Analisis & Nilai & Kriteria* \\
\hline Tanah : & & & \\
pH $\mathrm{H}_{2} \mathrm{O}$ & Elektrometrik & 5,44 & Masam \\
$\mathrm{N}-$ total $(\%)$ & Kjeldhal & 0,05 & Sangat Rendah \\
K-dd (me/100g) & Ekstraksi & 0,21 & Rendah \\
P-tersedia (ppm) & Bray II & 9,97 & Rendah \\
P-total $(\mathrm{ppm})$ & Destruksi & 308,91 & Rendah \\
C-organik $(\%)$ & Walkley \& Black & 0,32 & Sangat Rendah \\
Kadar air (\%) & Oven & 5,11 & Rendah \\
& & & \\
Pupuk kandang kotoran sapi: & & & \\
N (\%) & Kjeldhal & 1,38 & Tinggi \\
$\mathrm{K}_{2} \mathrm{O}(\%)$ & Destruksi & 0,86 & Tinggi \\
$\mathrm{P}_{2} \mathrm{O}_{5}(\%)$ & Destruksi & 0,74 & Tinggi \\
$\mathrm{C}$-organik $(\%)$ & Walkley \& Black & 27,05 & Tinggi \\
$\mathrm{C} / \mathrm{N}$-ratio & & 19,60 & Sedang \\
\hline
\end{tabular}

Sumber: Laboratorium Ilmu Tanah Unila (2016) dan *= Balai Penelitian Tanah (2009)

Tabel 2. Hasil analisis $\mathrm{C}$-organik dan $\mathrm{pH}_{2} \mathrm{O}$ tanah pasca galian $\mathrm{C}$ yang diinokulasi FMA dan ditambah bahan organik setelah panen.

\begin{tabular}{ccc}
\hline Perlakuan & C-Organik (\%) & $\mathrm{pH} \mathrm{H}_{2} \mathrm{O}$ \\
\hline $\mathrm{M}_{0} \mathrm{~B}_{0}$ & 1,4 & 6,8 \\
$\mathrm{M}_{0} \mathrm{~B}_{1}$ & 2,6 & 7,1 \\
$\mathrm{M}_{0} \mathrm{~B}_{2}$ & 3,2 & 7,0 \\
$\mathrm{M}_{0} \mathrm{~B}_{3}$ & 3,5 & 7,3 \\
$\mathrm{M}_{1} \mathrm{~B}_{0}$ & 1,0 & 6,8 \\
$\mathrm{M}_{1} \mathrm{~B}_{1}$ & 2,3 & 7,1 \\
$\mathrm{M}_{1} \mathrm{~B}_{2}$ & 3,7 & 7,1 \\
$\mathrm{M}_{1} \mathrm{~B}_{3}$ & 3,7 & 7,2 \\
$\mathrm{M}_{2} \mathrm{~B}_{0}$ & 1,3 & 6,2 \\
$\mathrm{M}_{2} \mathrm{~B}_{1}$ & 2,1 & 7,1 \\
$\mathrm{M}_{2} \mathrm{~B}_{2}$ & 2,5 & 7,0 \\
$\mathrm{M}_{2} \mathrm{~B}_{3}$ & 3,5 & 7,3 \\
\hline
\end{tabular}

Sumber : Laboratorium Ilmu Tanah Universitas Lampung (2016)

Keterangan: $\mathrm{M}_{0}=$ tanpa spora, $\mathrm{M}_{1}=250$ spora, $\mathrm{M}_{2}=500$ spora, $\mathrm{B}_{0}=$ tanpa bahan organik, $B_{1}=20 \%$ bahan organik, $B_{2}=40 \%$ bahan organik, dan $B_{3}=60 \%$ bahan organik 
dan tanaman yang mengeluarkan eksudat akar berupa karbon organik. Dosis FMA 250 spora dengan penambahan bahan organik sebanyak $40 \%$ dan $60 \%$ menunjukkan hasil C-organik yang paling tinggi yaitu 3,7\%. Selain itu, Refliaty et al. (2011) menyatakan bahwa C-organik meningkat seiring dengan meningaktnya dosis bahan organik yang diberikan ke dalam tanah. Bahan organik mengandung $\mathrm{C}$-organik yang tinggi, sehingga pada saat bahan organik terdekomposisi akan menghasilkan karbon yang selanjutnya akan diubah ke dalam bentuk humus.

Infeksi Akar. Inokulasi FMA pada akar tanaman jagung menunjukkan bahwa persen infeksi akar tertinggi diperoleh pada pemberian dosis 250 spora maupun 500 spora dibandingkan dengan tanpa inokulasi FMA(Tabel 3). Sedangkan, pada perlakuan bahan organik, persen infeksi akar tertinggi diperoleh pada tanpa penambahan bahan organik dan penambahan bahan organik $60 \%$, serta berbeda nyata dengan penambahan bahan organik $20 \%$ dan bahan organik $40 \%$.

Inokulasi FMA pada daerah perakaran tanaman jagung terbukti menunjukkan infeksi yang nyata. Terjadinya infeksi akar tanaman jagung yang tidak diberikan FMA menunjukkan bahwa terdapat FMA indigenous di dalam tanah pasca galian C. Infeksi akar tertinggi terjadi pada pemberian FMA 500 spora yaitu $50,69 \%$. Hal ini menunjukkan bahwa adanya pengaruh yang positif antara penambahan jumlah spora terhadap persen infeksi akar yang meningkat. Sedangkan, infeksi akar yang dipengaruhi oleh bahan organik menunjukkan hasil yang tidak konsisten, karena tanpa bahan organik dan penambahan bahan organik $60 \%$ sama-sama menunjukkan hasil infeksi akar yang tinggi.

Tingginya persen infeksi akar pada penambahan bahan organik $60 \%$ (46,78\%), diguga karena karbon yang tersedia akan memperbaiki kesuburan tanah, sehingga tanaman jagung akan tumbuh dengan baik. Hal ini akan mempengaruhi infektivitas FMA yang bersifat obligat simbion terhadap akar tanaman jagung. Bahan organik berinteraksi positif dengan FMA pada lahanlahan yang bermasalah seperti rendah unsur hara (Nurbaity, 2009). Selain itu, persen infeksi akar oleh FMA yang tidak diberi bahan organik memberikan hasil yang paling tinggi $(61,10 \%)$. Hal ini membuktikan bahwa FMA lebih efektif menginfeksi akar tanaman pada tanah yang miskin unsur hara sehingga keberadaannya lebih dimanfaatkan oleh tanaman. Hal ini sesuai dengan hasil penelitian Musfal (2010), infeksi akar tanaman jagung pada tanpa pemberian bahan organik meningkat seiring dengan bertambahnya dosis spora FMA hingga $15 \mathrm{~g}$ tanaman $^{-1}$. Serapan hara P dipengaruhi olah bahan organik.
Volume Akar. Inokulasi FMA pada akar tanaman jagung menunjukkan bahwa volume akar paling tinggi diperoleh pada pemberian dosis 250 spora yang tidak berbeda nyata dengan FMA 500 spora namun berbeda dengan tanpa FMA. Hasil volume akar terendah diperoleh pada tanpa inokulasi FMA (Tabel 4). Volume akar tanaman jagung yang diinokulasi oleh FMA meningkat secara nyata (Tabel 4). Hal ini menunjukkan terjadi simbiosis yang baik antara FMA dengan akar tanaman jagung. Pemberian dosis FMA 250 spora memberikan hasil yang tinggi dibandingkan dengan tanpa spora dan pemberian FMA 500 spora. Peningkatan volume akar oleh FMA diduga karena FMA mampu menyerap unsur-unsur hara yang tersedia di dalam tanah lebih banyak dibandingkan dengan tanpa FMA, sehingga meningkatkan volume akar. Hasil penelitian Erlita dan Hariani (2017) menunjukkan hasil yang sama bahwa volume akar tanaman jagung meningkat hingga pemberian dosis FMA $150 \mathrm{~g} \mathrm{plot}^{-1}$.

Tinggi Tanaman. Tinggi tanaman usia 2 MST pada tanpa inokulasi FMA yang ditambahkan bahan organik sebanyak $20 \%, 40 \%$ dan $60 \%$ menunjukkan hasil yang lebih tinggi dibandingkan dengan tanpa bahan organik. Inokulasi FMA 250 spora maupun 500 spora dengan tanpa bahan organik, tidak berbeda nyata dengan penambahan bahan organik $60 \%$ namun berbeda nyata dengan penambahan bahan organik $20 \%$ dan $40 \%$. Sedangkan penambahan bahan organik $(20 \%, 40 \%$, dan $60 \%$ ) yang dikombinasikan dengan FMA ( 250 spora dan 500 spora) menunjukkan hasil yang tidak berbeda nyata, namun berbeda dengan tanpa inokulasi FMA dan tanpa bahan organik (Tabel 5). Tinggi tanaman pada usia 2 minggu setelah tanam (MST) menunjukkan adanya interaksi antara FMA dan bahan organik. Tanpa pemberian bahan organik, inokulasi FMA berbagai dosis meningkatkan pertumbuhan tinggi tanaman dari 58,47 cm menjadi 59,97 cm dibandingkan dengan tanpa FMA $(43,93 \mathrm{~cm})$, namun setelah ditambahkan bahan organik berbagai dosis, tinggi tanaman menjadi sama antara tanaman yang diinokulasi FMA dengan tanpa FMA. Hal ini membuktikan bahwa FMA efektif menyerap unsur hara pada keadaan tanah yang rendah unsur hara (Widiastuti et al., 2003).

Selanjutnya, tanpa inokulasi FMA, penambahan bahan organik meningkatkan tinggi tanaman hingga 53,4 $\mathrm{cm}$ dibandingkan dengan tanpa bahan organik $(43,93$ $\mathrm{cm}$ ). Namun setelah diberi FMA berbagai dosis, tinggi tanaman paling tinggi terdapat pada tanpa bahan organik dan pemberian bahan organik $60 \%$. Pada kombinasi FMA dan tanpa bahan organik, diduga FMA menjadi lebih efekttif dalam membantu proses penyerapan unsur hara sehingga mempengaruhi proses pertumbuhan tinggi 
Tabel 3. Pengaruh inokulasi FMA dan bahan organik terhadap infeksi akar tanaman jagung.

\begin{tabular}{lc}
\hline Perlakuan & Infeksi Akar $(\%)$ \\
\hline Tanpa FMA & $9,74 \quad(2,86) \mathrm{b}$ \\
FMA 250 spora & $49,87 \quad(6.73) \mathrm{a}$ \\
FMA 500 spora & $50,69 \quad(6,75) \mathrm{a}$ \\
\hline BNT $_{0,05}$ & 1,19 \\
\hline Tanpa bahan organik & $61,10 \quad(7,54) \mathrm{a}$ \\
Bahan organik 20\% & $19,34 \quad(3,90) \mathrm{b}$ \\
Bahan organik 40 \% & $19,83 \quad(3,98) \mathrm{b}$ \\
Bahan organik 60\% & $46,78 \quad(6,39) \mathrm{a}$ \\
\hline BNT $_{0,05}$ & \multicolumn{2}{c}{1,37} \\
\hline
\end{tabular}

Keterangan: Nilai tengah yang diikuti oleh huruf yang sama, tidak berbeda nyata menurut uji BNT 5\%, angka dalam kurung adalah angka transformasi $(\sqrt{\mathrm{x}+0,5)})$.

Tabel 4. Pengaruh inokulasi FMA pada volume akar tanaman jagung.

\begin{tabular}{lc}
\hline Perlakuan & Volume akar $(\mathrm{ml})$ \\
\hline Tanpa FMA & $26,08 \mathrm{~b}$ \\
FMA 250 spora & $38,17 \mathrm{a}$ \\
FMA 500 spora & $32,83 \mathrm{ab}$ \\
\hline BNT $_{0,05}$ & 9,05 \\
\hline
\end{tabular}

Keterangan: Nilai tengah yang diikuti oleh huruf yang sama, tidak berbeda nyata menurut uji BNT 5\%.

Tabel 5. Interaksi inokulasi FMA dan penambahan bahan organik terhadap tinggi tanaman jagung 2 MST.

\begin{tabular}{|c|c|c|c|c|}
\hline \multirow[b]{2}{*}{ FMA } & \multicolumn{4}{|c|}{ Bahan Organik } \\
\hline & $\begin{array}{c}\text { Tanpa bahan } \\
\text { organik }\end{array}$ & $\begin{array}{c}\text { Bahan organik } \\
20 \%\end{array}$ & $\begin{array}{c}\text { Bahan organik } \\
40 \%\end{array}$ & $\begin{array}{c}\text { Bahan organik } \\
60 \%\end{array}$ \\
\hline & ‥ & 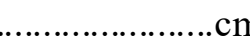 & 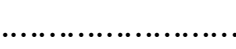 & ............. \\
\hline \multirow{2}{*}{ Tanpa FMA } & $43,93 b$ & $52,33 a$ & $50,67 \mathrm{a}$ & $53,4 a$ \\
\hline & $\mathrm{B}$ & A & A & A \\
\hline \multirow{2}{*}{$\begin{array}{l}\text { FMA } 250 \\
\text { spora }\end{array}$} & $59,97 \mathrm{a}$ & $46,2 \mathrm{bc}$ & $44,37 \mathrm{c}$ & $53,97 \mathrm{ab}$ \\
\hline & A & A & A & A \\
\hline \multirow{2}{*}{$\begin{array}{l}\text { FMA } 500 \\
\text { spora }\end{array}$} & $58,47 \mathrm{a}$ & $46,70 \mathrm{~b}$ & $44,90 \mathrm{~b}$ & $52,90 \mathrm{ab}$ \\
\hline & A & A & A & A \\
\hline $\mathrm{BNT}_{0,05}$ & & & & 9,21 \\
\hline
\end{tabular}

Keterangan: Nilai tengah yang diikuti huruf sama pada kolom dan baris yang sama tidak berbeda nyata menurut BNT 5\%. Huruf kecil dibaca horizontal dan huruf besar dibaca vertikal. 
tanaman jagung. Kemudian, pada kombinasi FMA dengan bahan organik $60 \%$, diduga unsur hara telah tersedia, dan FMA membantu tanaman jagung dalam menyerapan unsur hara tersebut. Hal ini sesuai dengan hasil penelitian Hutauruk et al. (2012), terjadi interaksi antara pemberian FMA dan pupuk fosfat terhadap tinggi tanaman sorgum pada usia 2 dan 3 MST, dimana tinggi tanaman tertinggi diperoleh pada kombinasi FMA dosis $10 \mathrm{~g}$ tanaman $^{-1}$ dengan pupuk fosfat dengan dosis 128 $\mathrm{kg} \mathrm{ha}^{-1}\left(2 \mathrm{~g} \mathrm{tan}^{-1}\right)$.

Tinggi tanaman jagung mengalami peningkatan setiap minggunya hingga minggu ke 8 (Gambar 1.). Inokulasi FMA meningkatkan pertumbuhan tinggi tanaman dan hasil yang paling tinggi terdapat pada perlakuan $M_{1}$. Sedangkan tinggi tanaman yang paling rendah terdapat pada perlakuan $\mathrm{M}_{0}$. Pengaruh penambahan bahan organik terhadap tinggi tanaman jagung yang mengalami peningkatan setiap minggunya. Dari grafik di bawah dapat dilihat bahwa tinggi tanaman jagung tertinggi adalah pada penambahan bahan organik $\mathrm{B}_{3}$.

Serapan Hara P Tanaman Jagung. Serapan hara $P$ tanaman jagung yang paling tinggi diperoleh pada penambahan bahan organik sebanyak $40 \%$ dibandingkan dengan bahan organik $20 \%$ dan $60 \%$. Sedangkan serapan hara $\mathrm{P}$ yang terendah diperoleh pada tanpa bahan organik (Tabel 6). Pemberian bahan organik hingga 40\% meningkatkan serapan hara P sebesar 26,65 g tanaman ${ }^{-1}$, namun menurun pada pemberian $60 \%$ bahan organik. Hal ini diduga karena pada batas pemberian dosis bahan organik $40 \%$, kebutuhan hara $\mathrm{P}$ tanaman jagung sesuai bagi kebutuhan tanaman jagung,

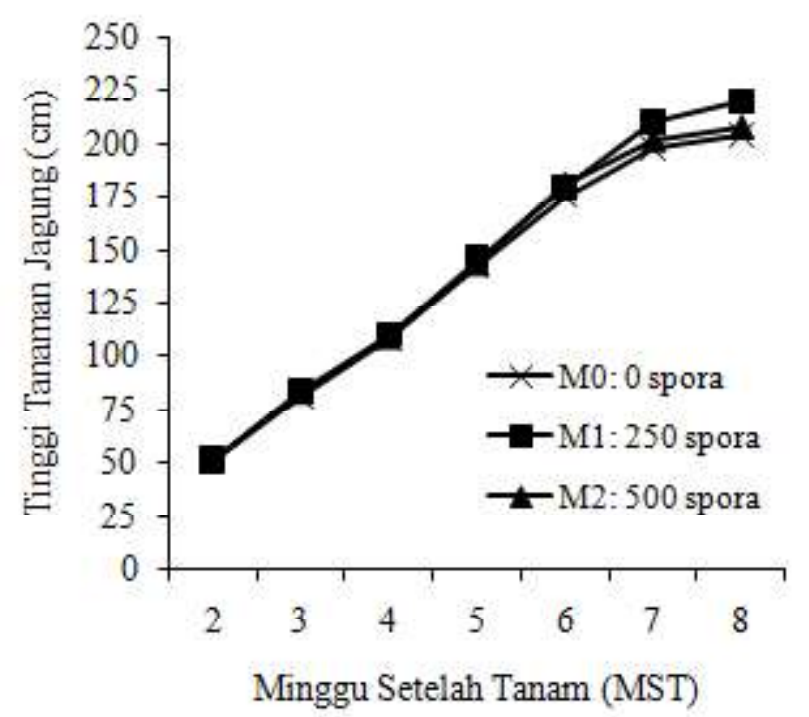

Gambar 1. Pengaruh inokulasi FMA terhadap tinggi tanaman jagung. sehingga tidak terjadi kekurangan atau kelebihan unsur hara bagi tanaman jagung.

Hasil penelitian ini sejalan dengan penelitian Bustami et al. (2012) bahwa peningkatan dosis pupuk fosfat yang diberikan pada tanaman padi $\left(0 \mathrm{~kg} \mathrm{ha}^{-1} ; 40\right.$ $\left.\mathrm{kg} \mathrm{ha}^{-1} ; 100 \mathrm{~kg} \mathrm{ha}^{-1}\right)$ memberikan hasil yang semakin menurun $(0,19 \% ; 0,18 \% ; 0,17 \%)$. Hal ini diduga karena pemupukan yang diberikan dengan dosis yang tinggi memberikan respon yang rendah bagi tanaman padi dalam menyerap fosfor. Selain itu, Tawakal (2009) menyatakan bahwa produksi tanaman meningkat hingga titik optimum dan turun setelah melewati batas optimum pemberian pupuk kandang.

Hubungan Antara Sifat Kimia Tanah dengan Pertumbuhan, Serapan Hara P dan Infeksi Akar

Tabel 6. Pengaruh penambahan bahan organik terhadap serapan hara P tanaman jagung.

\begin{tabular}{cc}
\hline \multicolumn{1}{c}{ Perlakuan } & $\begin{array}{c}\text { Serapan Hara P } \\
\left(\mathrm{g} \mathrm{tanaman}^{-1}\right)\end{array}$ \\
\hline Tanpa bahan organik & $13,97(3,69) \mathrm{b}$ \\
Bahan organik $20 \%$ & $18,09(4,21) \mathrm{b}$ \\
Bahan organik 40 \% & $26,65(5,04) \mathrm{a}$ \\
Bahan organik 60\% & $17,25(4,10) \mathrm{b}$ \\
\hline $\mathrm{BNT}_{0,05}$ & 0,67
\end{tabular}

Keterangan: Nilai tengah yang diikuti oleh huruf yang sama tidak berbeda nyata menurut uji BNT 5\%, angka di dalam kurung adalah angka transformasi .

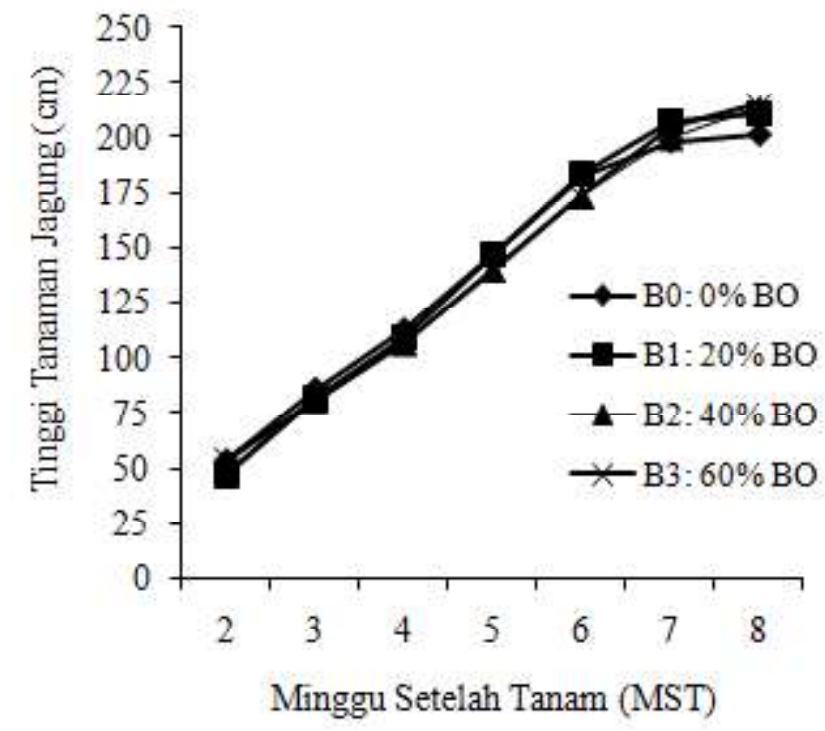

Gambar 2. Pengaruh penambahan bahan organik terhadap tinggi tanaman jagung. 
Tanaman Jagung. Hasil uji korelasi menunjukkan pH tanah berkorelasi dengan tinggi tanaman jagung pada 8 MST dan infeksi akar tanaman jagung, namun tidak berkorelasi dengan volume akar dan bobot brangksan kering tanaman jagung serta serapan hara $\mathrm{P}$ tanaman.Sedangkan hasil uji korelasi C-organik dengan tinggi tanaman 8 MST dan serapan hara P tanaman menujukkan korelasi yang sangat nyata dan tidak berkorelasi dengan volume akar, bobot brangkasan kering dan infeksi akar tanaman jagung (Tabel 7). Dari Tabel 7 tersebut dapat dilihat bahwa $\mathrm{pH}$ tanah dan C-organik berkorelasi positif dengan pertumbuhan tinggi tanaman, pada keadaan tanah yang memiliki $\mathrm{pH}$ 6,0-7,0 hampir semua unsur hara khususnya $\mathrm{P}$ tersedia bagi tanaman dalam jumlah yang optimum. Hal ini pula yang diduga menyebabkan $\mathrm{pH}$ tanah dan infeksi akar berkorelasi negatif. Tingginya kandungan P-tersedia pada tanah menyebabkan infeksi akar tanaman jagung menjadi rendah (Pulungan, 2013).

Kandungan C-organik diduga semakin menambah unsur hara di dalam tanah sehingga pertumbuhan tinggi tanaman jagung 8 MST meningkat, karena FMA lebih efektif menginfeksi tanaman inang pada keadaan tanah yang kurang subur. Selain itu,dapat dilihat pula bahwa $\mathrm{C}$-organik berkorelasi positif dengan serapan hara $\mathrm{P}$ tanaman jagung. Semakin tinggi kandungan $\mathrm{C}$-organik di dalam tanah maka akan semakin banyak pelepasan unsur hara $\mathrm{P}$ yang terjadi melalui hasil dekomposisi humus dan asam-asam organik di dalam tanah sehingga $\mathrm{P}$ organik dapat diubah menjadi $\mathrm{P}$ anorganik sehingga tersedia bagi tanaman. Hasil penelitian Khairuna et al. (2015) menunjukkan bahwa pemberian kompos dengan dosis $225 \mathrm{~g} \mathrm{pot}^{-1}$ mampu meningkatkan ketersediaan $\mathrm{P}$ tersedia tertinggi yaitu $1,18 \mathrm{mg} \mathrm{kg}^{-1}$.

Hubungan Antara Infeksi Akar dan Serapan Hara P Tanaman Jagung Tehadap Pertumbuhan Tanaman Jagung. Korelasi antara infeksi akar dan serapan hara $\mathrm{P}$ terhadap pertumbuhan tanaman dapat dilihat pada Tabel 8. Infeksi akar berkorelasi sangat nyata dengan volume akar namun tidak berkorelasi dengan tinggi tanaman 8 MST dan bobot brangkasan kering tanaman jagung. Hal ini disebabkan karena akar yang telah terinfeksi FMA akan menyerap unsur-unsur hara yang tersedia di dalam tanah lebih banyak dibandingkan dengan tanpa FMA, sehingga meningkatkan volume akar. Hasil penelitian Erlita dan Hariani (2017) menunjukkan hasil yang sama bahwa volume akar tanaman jagung meningkat hingga pemberian dosis FMA $150 \mathrm{~g} \mathrm{plot}^{-1}$.

Serapan hara $\mathrm{P}$ berkorelasi sangat nyata dengan pertumbuhan tanaman jagung (tinggi tanaman, volume akar, dan bobot berangkasan kering) (Tabel 8.). Hal ini dikarenakan P digunakan untuk pembentukan ATP dan NADPH dengan menggunakan bantuan cahaya matahari yang diserap oleh tanaman kemudian diubah menjadi energi kimia pada reaksi terang. Selanjutnya

Tabel 7. Rangkuman nilai koefisien korelasi antara sifat kimia tanah dengan pertumbuhan, serapan hara $\mathrm{P}$ dan infeksi akar tanaman jagung.

\begin{tabular}{cccccc}
\hline \multirow{2}{*}{ Variabel } & \multicolumn{5}{c}{ Koefisien korelasi (r) } \\
\cline { 2 - 6 } & $\begin{array}{c}\text { Tinggi Tanaman } 8 \\
\text { MST }(\mathrm{cm})\end{array}$ & $\begin{array}{c}\text { Volume } \\
\text { Akar }(\mathrm{ml})\end{array}$ & $\begin{array}{c}\text { Bobot Kering } \\
\text { Brangkasan }(\mathrm{g})\end{array}$ & $\begin{array}{c}\text { Infeksi } \\
\text { Akar }(\%)\end{array}$ & $\begin{array}{c}\text { Serapan Hara P } \\
\left(\mathrm{g} \mathrm{tanaman}^{-1}\right)\end{array}$ \\
\hline $\mathrm{pH}$ tanah & $0,33^{*}$ & $0,13^{\mathrm{tn}}$ & $0,25^{\text {tn }}$ & $-0,36^{*}$ & $0,19^{\text {tn }}$ \\
C-organik & $0,54^{* *}$ & $0,15^{\text {tn }}$ & $0,01^{\text {tn }}$ & $0,27^{\text {tn }}$ & $0,51^{* *}$ \\
\hline
\end{tabular}

Keterangan: $* *=$ berkorelasi sangat nyata, $\mathrm{tn}=$ tidak berkorelasi nyata

Tabel 8. Rangkuman nilai koefisien korelasi antara infeksi akar dan serapan hara P tanaman jagung terhadap pertumbuhan tanaman jagung.

\begin{tabular}{cccc}
\hline \multirow{2}{*}{ Variabel } & \multicolumn{3}{c}{ Koefisien kore lasi (r) } \\
\cline { 2 - 4 } & $\begin{array}{c}\text { Tinggi Tanaman } \\
8 \mathrm{MST}(\mathrm{cm})\end{array}$ & $\begin{array}{c}\text { Volume Akar } \\
(\mathrm{ml})\end{array}$ & $\begin{array}{c}\text { Bobot Berangkasan } \\
\text { Kering }(\mathrm{g})\end{array}$ \\
\hline Infeksi akar & $0,17^{\text {tn }}$ & $0,58^{* *}$ & $0,25^{\text {tn }}$ \\
Serapan hara P & $0,66^{* *}$ & $0,43^{* *}$ & $0,51^{* *}$ \\
\hline
\end{tabular}

Keterangan: $* *=$ berkorelasi sangat nyata, $\mathrm{tn}=$ tidak berkorelasi nyata 
pada reaski gelap, ATP dan NADPH digunakan untuk mereduksi $\mathrm{CO}_{2}$ untuk menghasilkan karbohidrat yang berlangsung di stroma (Salisbury \& Ross, 1995). Dengan kata lain, semakin banyak P yang diserap oleh tanaman maka pembentukan ATP dan NADPH akan semakin banyak sehingga $\mathrm{CO}_{2}$ yang tereduksi semakin banyak dan menghasilkan karbohidrat dalam jumlah yang banyak pula, sehingga akan mempengaruhi pertumbuhan tanaman jagung.

\section{KESIMPULAN}

Simpulan yang dapat diambil dari hasil penelitian ini bahwa inokulasi FMA pada tanaman jagung meningkatkan volume akar pada dosis 250 spora dan infeksi akar pada dosis 500 spora. Pemberian bahan organik meningkatkan tinggi tanaman, serapan hara $\mathrm{P}$ dan persen infeksi akar tanaman jagung. Pemberian bahan organik $40 \%$ memiliki serapan hara $\mathrm{P}$ yang lebih tinggi dibandingkan pemberian dosis bahan organik lainnya. Sedangkan tanpa pemberian bahan organik dan pemberian bahan organik $60 \%$ memiliki persen infeksi akar lebih tinggi dibandingkan pemberian bahan organik lainnya. Interaksi antara FMA dan bahan organik meningkatkan tinggi tanaman pada usia 2 MST pada kombinasi perlakuan FMA dengan tanpa bahan organik dan bahan organik dengan tanpa FMA.

\section{DAFTAR PUSTAKA}

Badan Penelitian dan Pengembangan Pertanian. 2008. Teknologi Budidaya Jagung. Bandar Lampung. $17 \mathrm{hlm}$.

Balai Penelitian Tanah. 2009. Analisis Kimia Tanah, Tanaman, Air, dan Pupuk. Departemen Pertanian. Bogor. $234 \mathrm{hlm}$.

Bustami, Sufardi, dan Bakhtiar. 2012. Serapan Hara dan Efisiensi Pemupukan Phosfat serta Pertumbuhan Padi Varietas Lokal. J. Manajemen Sumberdaya Lahan. Vol.1(2):159-170.

Cumming, J. R., and Ning J. 2003. Arbuscular Mycorrhizal Fungi Enchanced Aluminium Release from a Spodic Horizon Mediated by Organic Acids, Soil. Sci.Soc. Am. J. Vol.54: 17631767.

Erlita dan F. Hariani. 2017. Pemberian Mikoriza dan Pupuk Organik terhadap Pertumbuhan dan Produksi Tanaman Jagung (Zea mays). Agrium. Vol. 20(3): 268-272.
Hasibuan, D. S., T. Sabrina, dan A. Lubis. 2014. Potensi Berbagai Tanaman Sebagai Inang Inokulum Terhadap Pertumbuhan Tanaman Jagung dan Kedelai di Tanah Ultisol J.Online Agroteknologi. Vol.2(2): 905-914.

Hutauruk, F. I., T. Simanungkalit, T. Irmansyah. 2012. Pengujian Pemberian Fungi Mikoriza Arbuskula dan Pupuk Fosfat Pada Budidaya Tanaman Sorgum (Shorgum bicolor (L.) Moench). J.Online Agroekoteknologi. Vol.1(1): 64-76.

Khairuna, Syafruddin, dan Marlina. 2015. Pengaruh Fungi Mikoriza Arbuskular dan Kompos Pada Tanaman Kedelai Terhadap Sifat Kimia Tanah. J. Floratek. Vol.10: 1-9.

Musfal.2010. Potensi Cendawan Mikoriza Arbuskula untuk Meningkatkan Hasil Tanaman Jagung. $J$. Litbang Pertanian. Vol. 29(4): 154-158.

Nurbaity, A., D. Herdiyantoro, dan O. Mulyani. 2009. Pemanfaatan Bahan Organik Sebagai Bahan Pembawa Inokulan Fungi Mikoriza Arbuskula. $J$. Biologi. Vol.13(1): 7-11.

Pulungan, A. S. S. 2013. Infeksi Fungi Mikoriza Arbuskular Pada Akar Tanaman Tebu (Saccharum officinarum L.). J.Biosains Unimed. Vol.25(1): 43-46.

Refliaty, G. Tampubolon, dan Hendriansyah. 2011. Pengaruh Pemberian Kompos Sisa Biogas Kotoran Sapi Terhadap Perbaikan Beberapa Sifat Fisik Ultisol dan Hasil Kedelai (Glycine max (L.) Merill). J.Hidrolitan. Vol. 2(3): 103-114.

Salisbury, F. B dan C.W. Ross. 1995. Fisiologi Tumbuhan. Jilid 2. Terjemahan: Diah R. Lukman dan Sumaryono. Institut Teknologi Bandung. Bandung. 173 hlm.

Syekhfani. 1993. Peruntukan Lahan Wilayah Pertambangan Bahan Galian Golongan C (Sedimen Lepas). Disajikan dalam Lokakarya Petunjuk Teknis Reklamasi Lahan Bekas Penambangan Bahan Galian Golongan C di Jawa Timur, di Hotel New Victory Batu, Malang, BAPEDALDA JATIM pada tanggal 28-30 Oktober 1993. 6 hlm.

Tawakal, M. I. 2009. Respons Pertumbuhan dan Produksi Beberapa Varietas Kedelai (Glicine $\max$ L.) terhadap Pemberian Pupuk Kandang Kotoran Sapi. Skripsi. Universitas Sumatera Utara. Medan. 62 hlm. 
Widiastuti, H., Guhardja, E., Soekarno,N., Darusman, L. K., Goenadi, D. H., dan Smith, S. E. 2003. Optimasi Simbiosis Cendawan Mikoriza Arbuskular Acaulospora tuberculata dan Gigaspora margarita Pada Bibit Kelapa Sawit di Tanah Masam. Menara Perkebunan. Vol. 70(2): 50-57. 